\title{
Author Correction: Two decades of glacier mass loss along the Andes
}

\author{
I. Dussaillant (D), E. Berthier (iD, F. Brun (D), M. Masiokas, R. Hugonnet, V. Favier (iD, A. Rabatel(D), P. Pitte and L. Ruiz \\ Correction to: Nature Geoscience https://doi.org/10.1038/s41561-019-0432-5, published online 16 September 2019.
}

In the Supplementary Information for this Article, in Section 9 information about the hydrological datasets was missing, the following text has now been added: "Mean annual runoff values were derived from mean monthly data provided by Dirección General de Aguas, Chile (http://www.dga.cl), Secretaría de Infraestructura y Política Hídrica, Argentina (https://www.argentina.gob.ar/obras-publicas/ infraestructura-y-politica-hidrica), and Autoridad Nacional del Agua, Peru (https://www.ana.gob.pe).

A few missing months (March to July 2013) in the Santa river record in Peru were infilled using the corresponding long-term monthly means. If necessary, missing months in the Chilean and Argentinean river records were infilled with a weighted average of monthly values from highly correlated stations within the same river basin (for details see Masiokas et al. 2019)."

In Supplementary Table 3, there were errors in the data for the Baker basin; the gauging station used should have been Bajo Nadis instead of Desagüe Lago Bertrand, which affected the values of the annual mean river runoff, sub-period runoff change and the glacier imbalance contribution. For the annual mean river runoff $\left(\mathrm{m}^{3} \mathrm{~s}^{-1}\right), 649.2$ and 568.7 should have been 922.8 and 975.9, respectively; for the sub-period runoff change (\%), -12 should have been 6 ; and for the glacier imbalance contribution (\%), 3 and 5 should have been 2 and 3 , respectively. Related to this, in the sentence beginning "The two Patagonian basins..." in the final paragraph of the section "Influence of glacier mass loss on river runoff" in the main text of the Article, "3 to 5\%" should have been " 2 to $3 \%$ ”. Furthermore, in Supplementary Table 3, "Condorecerro" should have read "Condorcerro".

The online versions of the Article have been amended and the Supplementary Information file replaced.

Published online: 1 September 2020

https://doi.org/10.1038/s41561-020-0639-5

(c) The Author(s), under exclusive licence to Springer Nature Limited 2020

\section{Publisher Correction: The state of rock debris covering Earth's glaciers}

\author{
Sam Herreid (D) and Francesca Pellicciotti $(D$
}

Correction to: Nature Geoscience https://doi.org/10.1038/s41561-020-0615-0, published online 3 August 2020.

In the version of this Article originally published, the text 'regions with $n>70$ were excluded' in the caption of Fig. 5 was incorrect; it should have read 'regions with $n<70$ were excluded'. This has now been corrected.

Published online: 14 August 2020

https://doi.org/10.1038/s41561-020-0630-1

(c) The Author(s), under exclusive licence to Springer Nature Limited 2020 